\title{
38. GEOPHYSICAL OBSERVATIONS OF SLOPE DEPOSITS, MIDDLE AMERICA TRENCH OFF GUATEMALA ${ }^{1}$
}

\author{
Roland von Huene, U.S. Geological Survey, Menlo Park, California \\ John Ladd, Lamont-Doherty Geological Observatory, Palisades, New York \\ and \\ Ian Norton, Marine Science Institute, University of Texas, Galveston, Texas
}

\begin{abstract}
Slope deposits drilled during Leg 67 were later detailed in redisplayed seismic-reflection records. These deposits are of significantly lower seismic velocity and probably lower density than the underlying basement. This relationship indicates a contact between rocks of differing consolidation rather than a continuous sedimentary sequence. The slope deposits cover basement terranes of three different topographies. The shelf edge is an arch whose seaward flank forms a steep (up to $15^{\circ}$ ) upper slope. The midslope area has a rugged topography covered by thick slope deposits. The lower slope is relatively smooth except where broken locally by benches. The upper and middle slope areas are associated with strong magnetic anomalies and rare, landward-dipping reflections truncated by the rough surface. The rough midslope topography may reflect erosion succeeding the Paleocene uplift of this area and at least local subsidence in the early Miocene. Slope deposits covered the Trench landward slope, contemporaneous with the increased arc volcanism indicated by ash layers and with the present period of subduction.

The subducting ocean crust and sediment of the Cocos Plate has a linear horst and graben topography of hundreds of meters relief that disappears beneath the landward slope of the Trench without disturbing its topography. This passive assimilation of oceanic material without significant accretion in the late Neogene argues for significant decoupling at the front of the subduction zone.

A base of gas-hydrate reflection is evident in many of the redisplayed seismic records off Guatemala. These reflections are most common where slope deposits are thick; the reflections have not been identified in the underlying acoustic basement. This observation is consistent with the geochemical evidence that gas hydrate has its source in the organic-rich slope sediment. The hydrate depth and the temperature measurements in drill holes indicate a temperature gradient of $30^{\circ} \mathrm{C} / \mathrm{km}$.
\end{abstract}

\section{INTRODUCTION}

In preparation for the IPOD drilling of the Middle America Trench transect off Guatemala, the University of Texas made a grid pattern of geophysical observations that included seismic-refraction, seismic-reflection, magnetic, and bathymetric measurements (Ladd et al., this volume). Following Leg 67, a Seabeam survey was made by CNEXO (Aubouin et al., Seabeam Survey, this volume). The IPOD and some of the earlier surveys were made to study the deep structure of the arc-trench system, concentrating on the refraction crustal velocity structure (Shor and Fisher, 1961; Ibrahim et al., 1979), the crustal structure as modeled from gravity and magnetic observations (Couch and Woodcock, 1981), and the configuration of deep seismic reflections (Seely et al., 1974; Ladd et al., 1978; Ladd et al., this volume). Most of the IPOD drilling, however, did not penetrate to the horizons significant to the crustal geophysical studies. In this paper we focus on the uppermost 2- to $4-\mathrm{km}$ sub-bottom interval of the Guatemalan margin through reexamination of seismic-reflection records, most of which have been scaled and redisplayed using parameters that emphasize the shallow structure and particularly any reflections developed on the base of the

\footnotetext{
${ }^{1}$ Aubouin, J., von Huene, R., et al., Init. Repts. DSDP, 67: Washington (U.S. Govt. Printing Office).
}

gas-hydrate zone (Fig. 1). The new discoveries during Leg 67 have prompted examination of features, such as gas hydrates, which were not investigated in earlier studies. Through this study we have reconciled some of the differences between interpretations of the geophysical data made prior to drilling and the interpretation of data from the Leg 67 cores.

\section{SEISMIC CHARACTER OF SLOPE SEDIMENT}

\section{Velocity}

Seismic velocity was measured in three ways: first, on the core aboard the Challenger with a Hamilton frame (Boyce, 1976); second, by making the normal moveout correction during processing of the seismic-reflection data; and third, with the refraction measurements. Velocity measurements on the Site 494 cores gave an almost constant value of $1.7 \mathrm{~km} / \mathrm{s}$ in slope deposits and values of 3.5 to $4.0 \mathrm{~km} / \mathrm{s}$ from underlying sedimentary and igneous rock. At Sites 496 and 497 velocity measurements were difficult to make because of the large amount of entrained gas, but when a value of $1.6 \mathrm{~km} / \mathrm{s}$ was assumed, the features in seismic-reflection records correlated well with those penetrated by the drill.

The velocities of slope sediment indicated by semblance analysis are generally between 1.5 and $1.7 \mathrm{~km} / \mathrm{s}$ (Ladd et al., this volume). When the base of the slope 


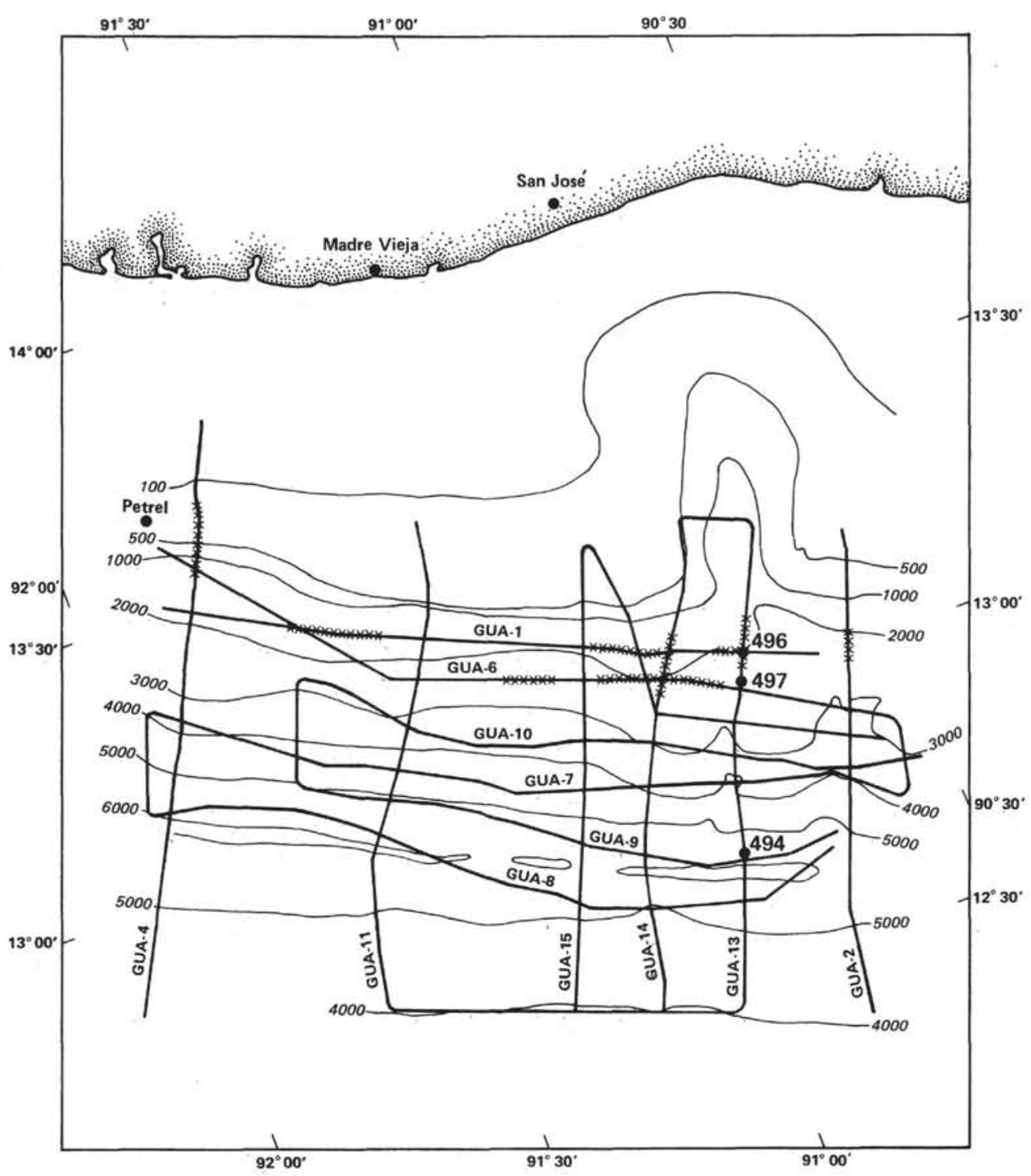

Figure 1. Ships' tracks of multichannel seismic-reflection records made in 1977 by the University of Texas as a site survey for IPOD. (Location of Leg 67 drill sites and industry wells are shown by circles. Bathymetry in 1000-m contours.)

sediment is well defined, the semblance analysis generally indicates a nearly constant velocity value in the first 500 meters of slope deposits and then a very rapid increase in velocity in the underlying rock.

In seismic-refraction measurements the uppermost units have velocities from 1.8 to $2.5 \mathrm{~km} / \mathrm{s}$ (Shor and Fisher, 1961; Ibrahim et al., 1979). Some of these velocities are too high for slope deposits and are instead derived from the interface at or below the base of the deposits, which, for convenience, is here called the acoustic basement despite local reflection within it. ${ }^{2}$ The thinness, the irregular bedding, and the roughness of the basement surface commonly made the refraction mea-

\footnotetext{
2 "Acoustic basement" in the seismic-reflection records has two meanings. If it represents the interface between rocks of the continental framework and sediment of the overlying slope deposits, we refer to this surface simply as basement. This usage does not imply continental, intermediate, or other types of crustal structure. When "basement" is used to denote the top of the igneous oceanic crust it is prefaced by "oceanic."
}

surements difficult. In three refraction stations, velocities of 1.6 to $2.0 \mathrm{~km} / \mathrm{s}$ were obtained from horizons clearly within the slope deposits (Stations 1, 3, and 8, Ibrahim et al., 1979). Within the zone of coherent reflections at the base of the slope deposits, refraction velocities are locally as high as $2.1 \mathrm{~km} / \mathrm{s}$, and in the basement immediately below the slope deposits they range from 2.3 to $3.3 \mathrm{~km} / \mathrm{s}$. Hamilton frame, reflection, and refraction measurements indicate that the velocity contrast between slope deposits and the underlying rock that forms an acoustic basement can generate relatively large reflection coefficients, particularly if the contrasting units are in sharp contact. The contrast produces strong reflections from the base of the slope deposits. At the other extreme, a low velocity contrast, a complex contact, or a depth of burial great enough to mute the seismic expression of the base of the slope deposits will generate no strong reflection at the base of the slope deposits. 


\section{Identification of Basement}

Acoustic basement at the base of the slope deposits is commonly an irregular surface associated almost everywhere with diffractions (Fig. 2). These diffractions have at their crests a very high amplitude and are of a frequency lower than the overlying reflections. The sharpest contact between basement and slope deposits is a single diffractive reflection, but more often multiple overlapping diffractions are seen.

The first criterion we used to identify the base of the slope deposits is the high-reflection amplitude that results from the general contrast in velocity and/or density between slope deposits and underlying rock. Secondary criteria are a diffractive character and a general continuity of reflection in slope deposits and lack of continuity in the underlying rocks. The boundary chosen could easily be shifted by one or more phases, because only rarely is the contact sharply displayed. The diffuse nature of the contact is probably as much a function of recording multiple events from both in and outside of the plane of section as it is a function of a complex or gradational boundary. The amplitude of the reflection is commonly as great or greater than the reflection at the seafloor, despite sub-bottom depths of
0.5 to $1 \mathrm{~km}$. This relationship would not be the case if a broadly gradational velocity increase marked the boundary. As indicated previously, the velocity increase at the base of the slope deposits can be $0.6 \mathrm{~km} / \mathrm{s}$ to perhaps as large as $3.0 \mathrm{~km} / \mathrm{s}$, whereas the increase at the seafloor is about $0.2 \mathrm{~km} / \mathrm{s}$. We have little information on density, but a similar shift in rock density would be expected. The amplitude criterion, however, sometimes fails, especially on the lower slope, and locally it cannot be applied without consideration of reflection continuity and structure. Thus the interpretation of basement depth is locally very uncertain.

\section{Nature of the Base of the Slope Deposits Surface}

The broad morphology of the basement surface follows in a subdued way the topography of the landward slope of the Trench (Fig. 3). Overall, the seafloor topography of the Trench slope deepens $6 \mathrm{~km}$ in about 60 $\mathrm{km}$, but its uppermost 2000 meters generally consist of a steep slope, the next 1000 meters are the least steep, and the lowermost portion is commonly a steep surface marked locally by gullies and steplike benches. The largest canyon, San José Canyon, has eroded more than 1 $\mathrm{km}$ into the sedimentary sequence at the edge of the shelf and the upper slope, but the canyon becomes ob-

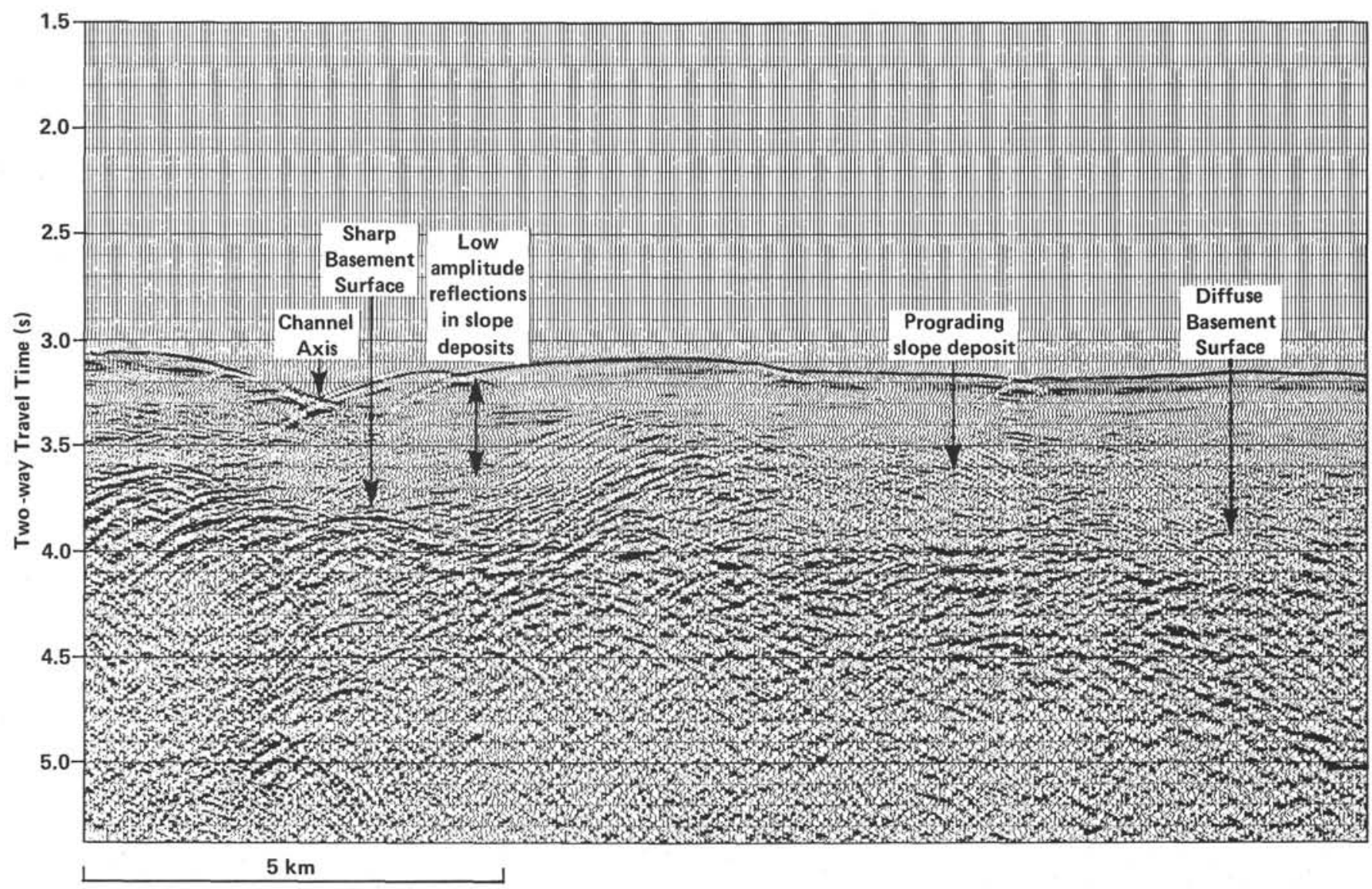

Figure 2. A portion of record GUA-6 parallel to the strike of the Trench in the midslope area showing the amplitude contrast between slope deposits and the top of the continental framework. (This display was made without AGC [Automatic Gain Control] and at a low gain to prevent clipping. VE is 3.3:1.) 


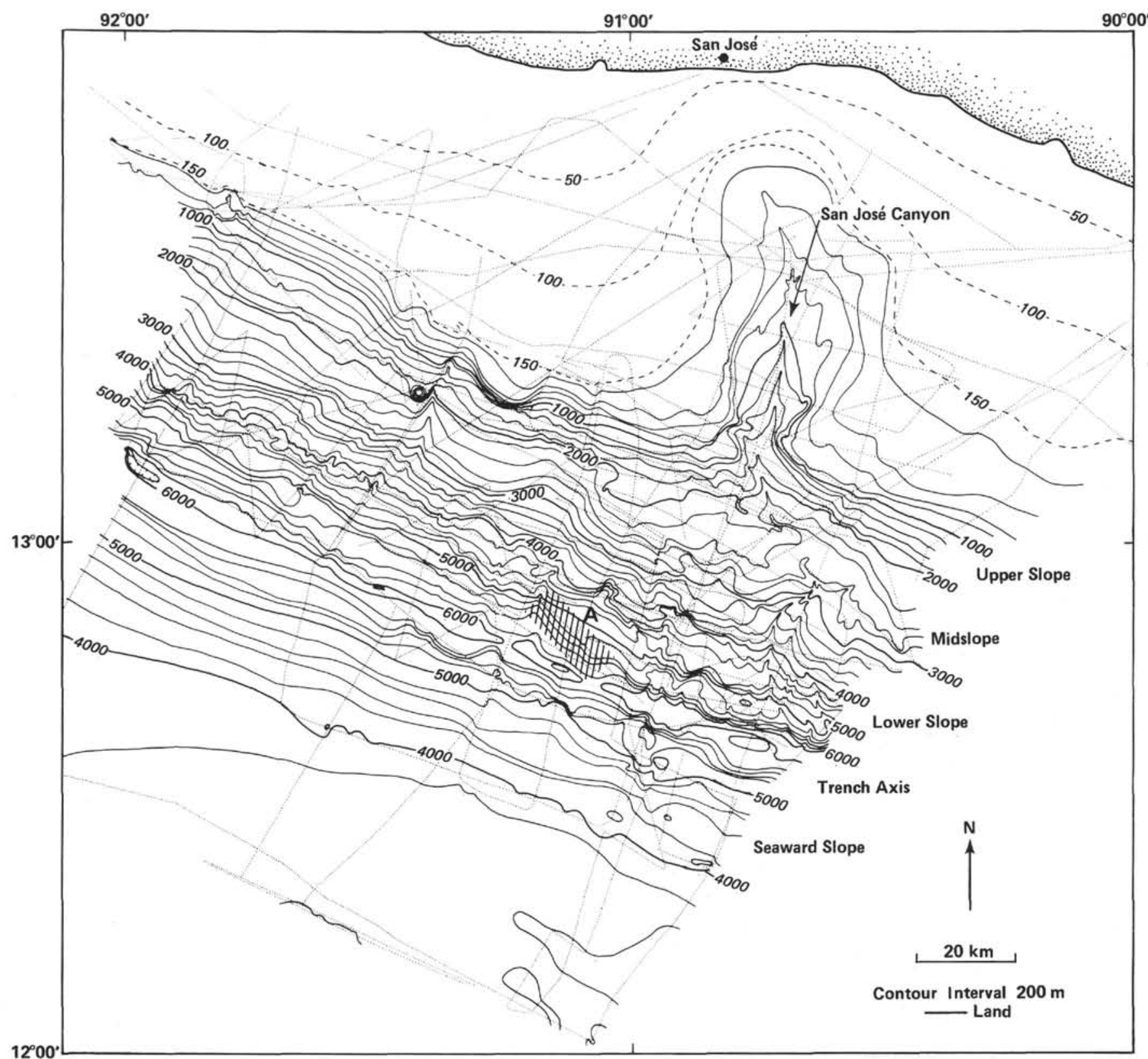

Figure 3. Bathymetric map from University of Texas data. (Contour interval $=200 \mathrm{~m}$. Area A at the foot of the slope has a trend that may reflect the collision of a large ridge with the slope, as explained in the text.)

scure on the lower slope and indistinguishable from the numerous smaller canyons that traverse all parts of the slope.

The gross topography of the basement (Fig. 4) is divided into: (1) a 1.5-km-long drop-off beginning at the edge of the continental shelf and extending at an average dip of $12^{\circ}$ beneath the upper slope; (2) a middle slope area with gentle dips averaging $2^{\circ}$ and local relief as large as $1 \mathrm{~km}$; and (3) a lower slope interval of moderate dips averaging $5^{\circ}$ and generally smooth relief except where cut by a series of benches. A map of the basement surface contrasts the rough topography of the midslope with the smoother topography of the upper and lower slopes (Fig. 5).

Bedding in the basement is locally apparent. Parts of the basement surface truncate faint bedding on records trending both parallel and perpendicular to the slope. Deep landward-dipping reflectors on record GUA-13 are emphasized by Ladd et al. (this volume). These layers are truncated at the basement surface, especially in the midslope area. Along portions of records paralleling the regional trend, bedding in the basement conforms locally to the surface of the base of slope deposits as well. Erosional truncation of beds is clearly seen in upper San José Canyon (Fig. 6). The basement surface is now covered by sediment filling the canyon, suggesting multiple stages of erosion and deposition perhaps related to channel migration. Elsewhere the truncation is not so clearly defined. Whether the basement surface originated by tectonism or erosion is unclear from the geometry of bedding alone; the process appears to have involved multiple mechanisms. 


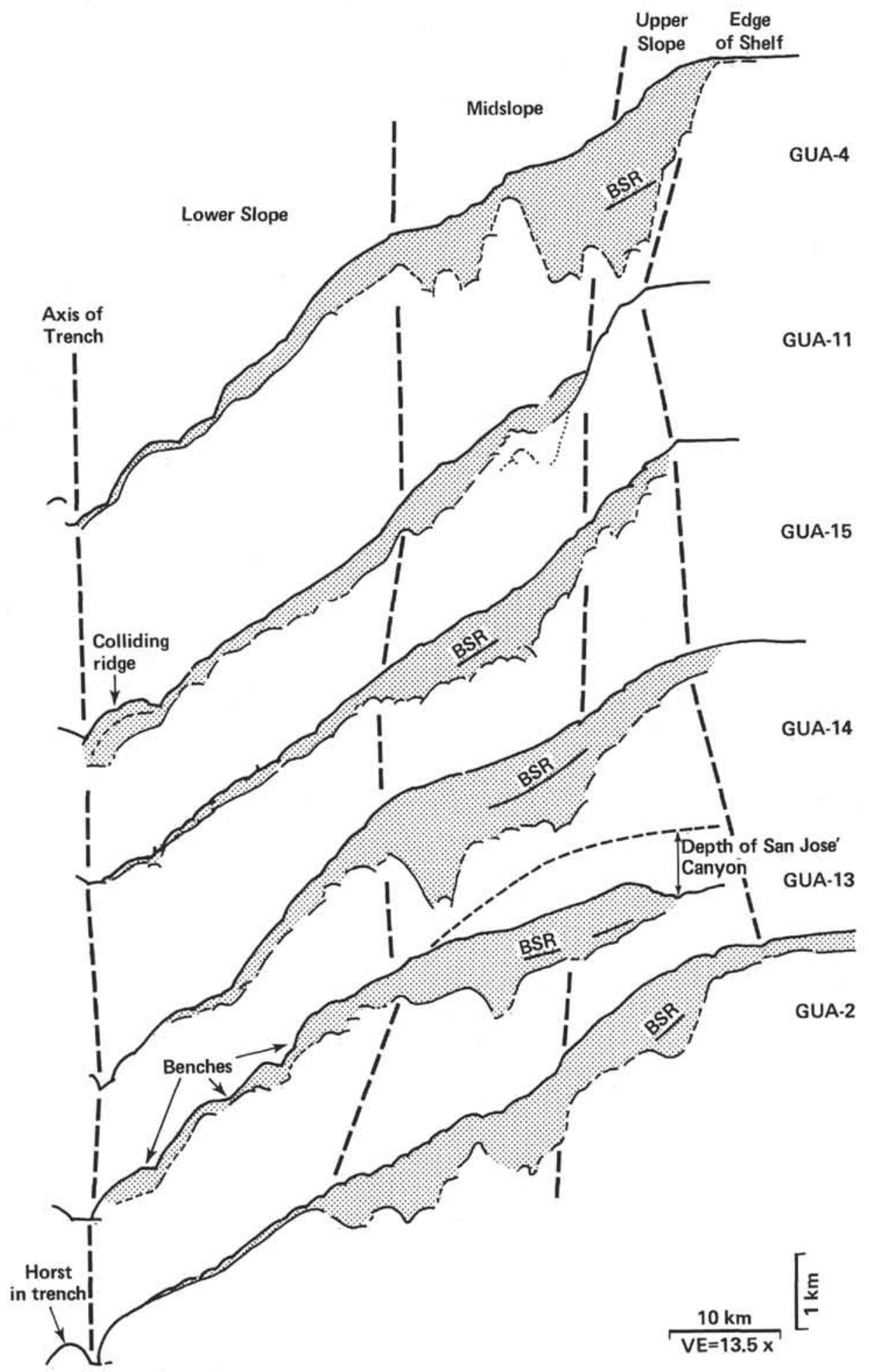

Figure 4. Sections across the slope along seismic records showing the base of the slope deposits and prominent BSRs (bottom simulating reflectors). (Records GUA-2 and GUA-13 include parts of San José Canyon, and the dashed line in GUA-13 shows configuration of the seafloor along one side of the Canyon.)

\section{Reflection Character in Slope Deposits}

Bedding within the slope deposits is best resolved along the upper slope, and the resolution degrades progressively downslope as the distance of reflectors from the seismic source and receiver increases. In the middle slope area of relatively gentle dip, maximum slope deposit thickness in troughs is about $1 \mathrm{~km}$. Reflections are sometimes continuous for $7 \mathrm{~km}$ in lines parallel to the slope. At the other extreme are areas without many coherent reflections. On the lower slope of the Trench, a uniform cover of diffractive short reflections is most 


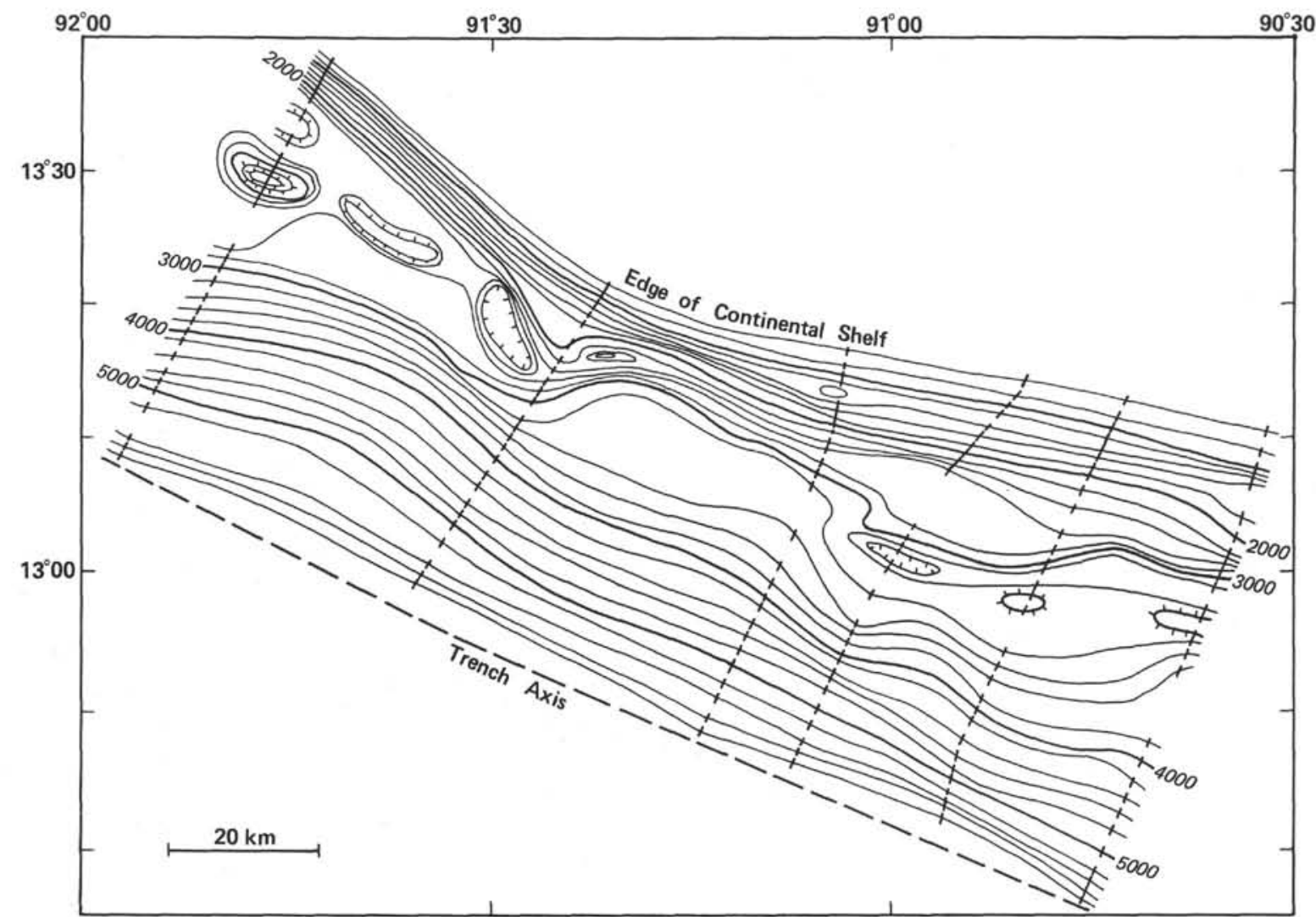

Figure 5. Contours on the base of the slope deposits from all multichannel seismic data. (Only the lines across the margin are shown; see Fig. 1 for other lines used. The contours begin at the edge of the slope and end at the Trench axis. The irregularity of the midslope is generalized because of the wide spacing of ships' tracks relative to the roughness of the topography. Contour interval $=200 \mathrm{~m}$.)

common, and little sedimentary structure can be determined.

Structure in the middle slope where sediment has collected most rapidly shows local, thin, reflective sequences conforming to the basement surface, often of only 1 or 2 reflections of high frequency. More commonly, the reflections lap onto, or abut, the rough basement surface, or a general zone of seismic "hash" covers basement (Fig. 2). Above the basal zone are local reflection patterns suggesting lobate or fine overbank strata as well as ponded sediment (Fig. 7). The overall clarity of the record is insufficient to make good estimates of the amount of sediment transported by the various processes. This result is in part due to the lack of velocity contrast in the section, as shown by the general low-amplitude-high-frequency reflections that are consistent with the muddy section that was drilled (Figs. 2 and 8). A seismic system with a greater band width than the one used in this study might better resolve structure within slope sediments.

\section{STRUCTURE IN SLOPE DEPOSITS AROUND THE LEG 67 DRILL SITES}

The preceding provides a general background for the more specific description of seismic-reflection records at Sites 496 and 497 . The following interpretations supersede those in the site chapters because the interpretation here is based on seismic displays not available during preparation of the site chapters.

\section{Sites 496 and 497, Upper Slope}

At upper slope Sites 496 and 497 (Fig. 1) the main objective was to penetrate to the landward-dipping reflection described by Ladd et al. (this volume), but it was not reached because gas hydrate was encountered (von Huene, Aubouin, et al., 1980). An expanded, restacked, and rescaled section of part of seismic record GUA-13 (Fig. 7) indicates penetration at Site 496 of the hemipelagic slope muds that lap onto a lobate body, which in turn downlaps the basement surface above the landward-dipping reflection. Cutting the lower unit is a base of gas-hydrate reflection commonly called a bottom simulating reflector, or BSR. Drilling at Site 496 penetrated a unit of biogenic mud, an unconformity $(0.25 \mathrm{~s}$ deep), a thin mud unit that had accumulated slowly, and finally a semilithified, lower Miocene, sandy mudstone. Both the upper and lower units have abundant terrigenous detritus, volcanic ash, and rare lignite.

Seismic record GUA-1B crossing at the Site but perpendicular to GUA-13 shows a 5-km-wide, low mound of sediment with strata overlapping it (Fig. 8). The overlying strata are part of the fill of San José Canyon. It is not clear whether the lobate sediment body is part of an ancient canyon fill or part of the material deformed and then eroded by the Canyon. The initial age of canyon cutting is thought by J. W. Ladd and S. C. Schroder (personal communication, 1981) to have started in the early Miocene or late Oligocene. The age of the 


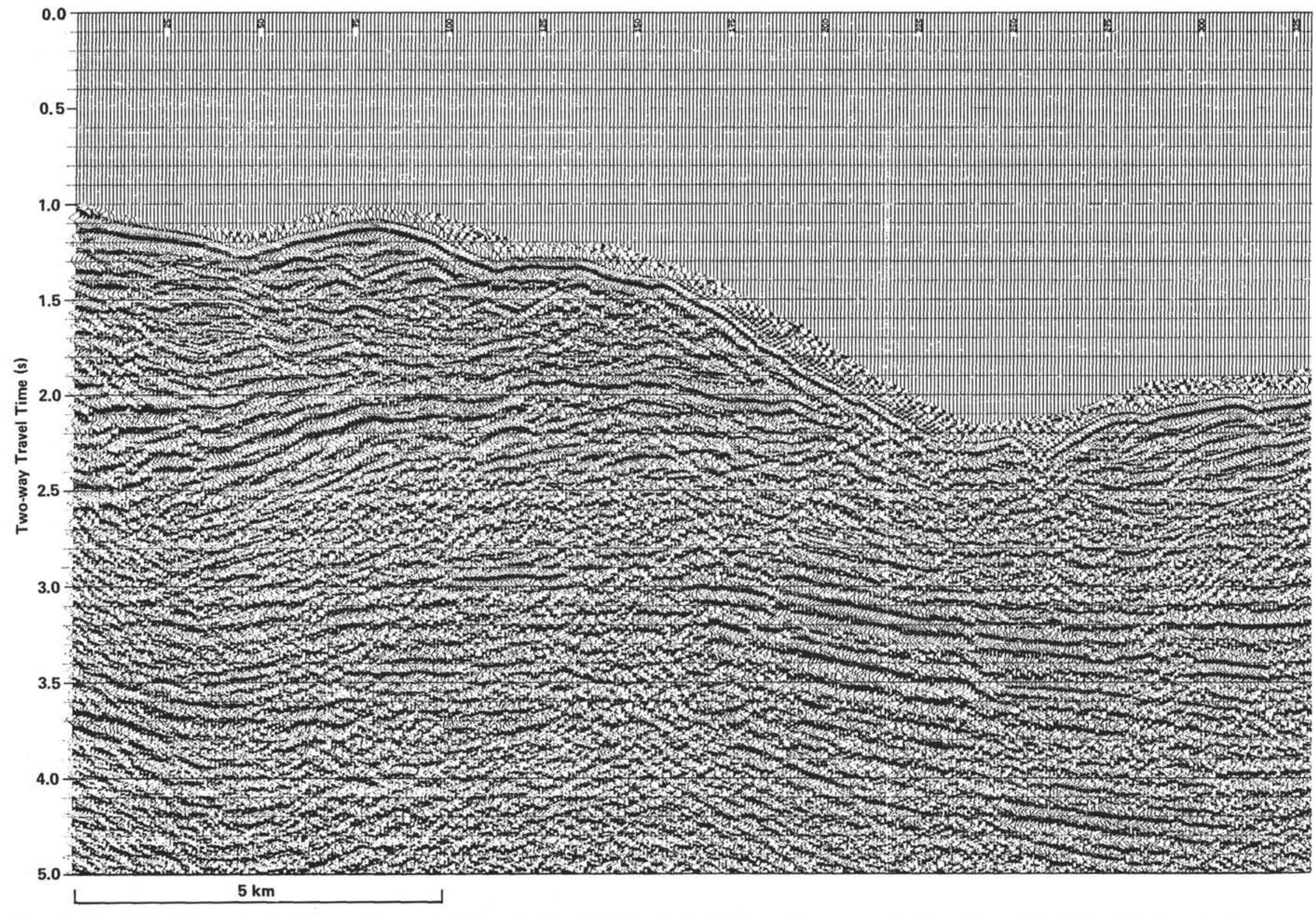

Figure 6. Part of GUA-28 across San José Canyon. (The prominent discontinuity on the left bank is the Oligocene-Miocene unconformity, and truncated reflectors indicate erosion.) 

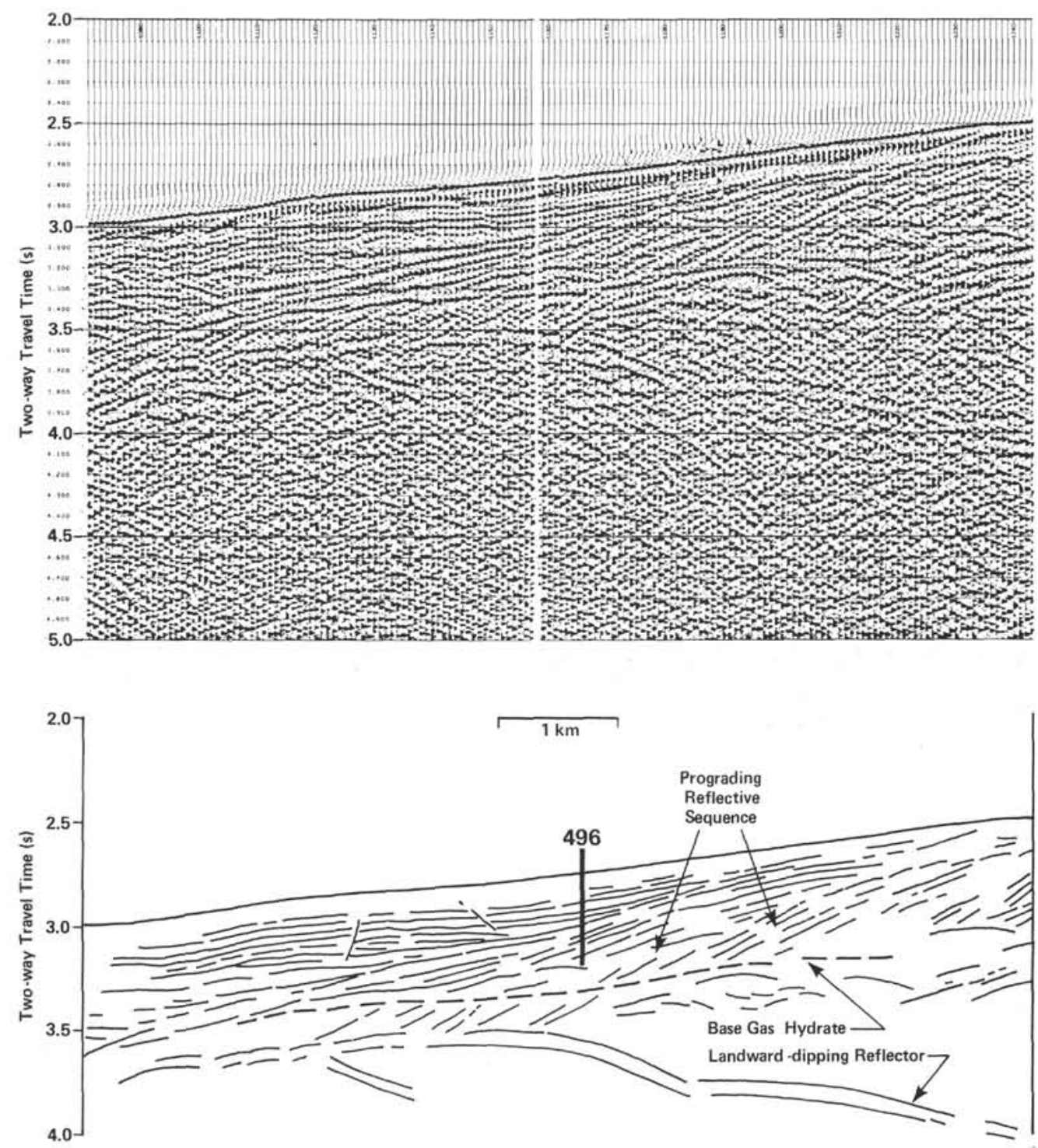

Figure 7. Part of seismic record GUA-13 across the midslope where Site 496 was drilled, and an interpretive line drawing showing the structure of the slope deposits and a base of gas hydrate BSR. (The landwarddipping reflection described by Ladd et al. [this volume] is on the right.)

lobate sediment body is early Miocene (Site 496 report, this volume).

The seismic and drill data indicate that at Site 496 a Quaternary and Pliocene hemipelagic slope sequence covered a lobate body of early Miocene prograding sediment. This sediment was deposited in neritic water depths (Thompson, this volume) that was cut off from rapid slope sedimentation during the middle and part of the late Miocene, perhaps because it stood above the surrounding slope and was separated from its former feeder channel. The sediment lobe may have been associated with an early equivalent of San José Canyon.

\section{GEOPHYSICAL EVIDENCE OF GAS HYDRATE}

Since the first encounter of gas hydrate in the core from Hole 496, a renewed effort was made to find bottom simulating reflections that would indicate the base of gas hydrates (Shipley et al., 1979). Shipley had in- formally noted a possible gas hydrate in GUA-14 prior to drilling, but the evidence in other records was not convincing. After Leg 67, an expanded display of the GUA-14 traces was made to show a polarity reversal of the BSR as compared with the seafloor polarity (Fig. 9), the expected response to a reflection from the interface of a high-velocity hydrate over a low-velocity, gascharged sediment (Ladd et al., this volume).

The seismic records were redisplayed with scaling factors that enhanced the BSRs and the structure of slope deposits (short AGC [Automatic Gain Control] window, no variable gain, and no filtering of high-frequency data). Shipley et al. (1979) plotted water depth versus depth to sub-bottom reflectors, and the field of about 25 points from Guatemala fits the field of the base of the hydrated zone well (Fig. 10). Parts of two Guatemala BSRs do not fall within the field shown for Guatemala. This observation is explained as follows: a con- 


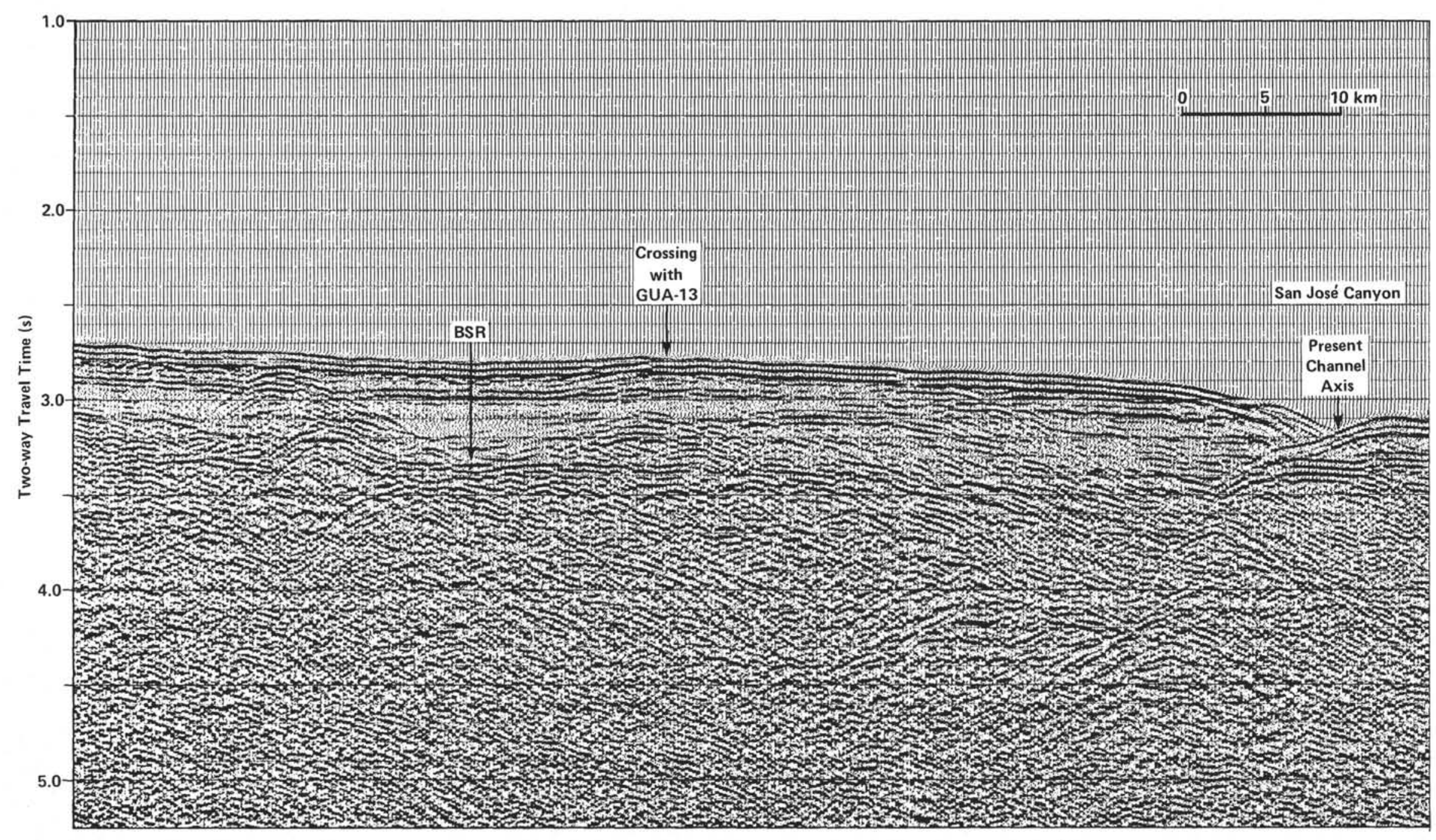

Figure 8. Part of record GUA-1B that crosses GUA-13 at Site 496 (Fig. 1), showing the prograding sediment lobe and its relation to San José Canyon. 


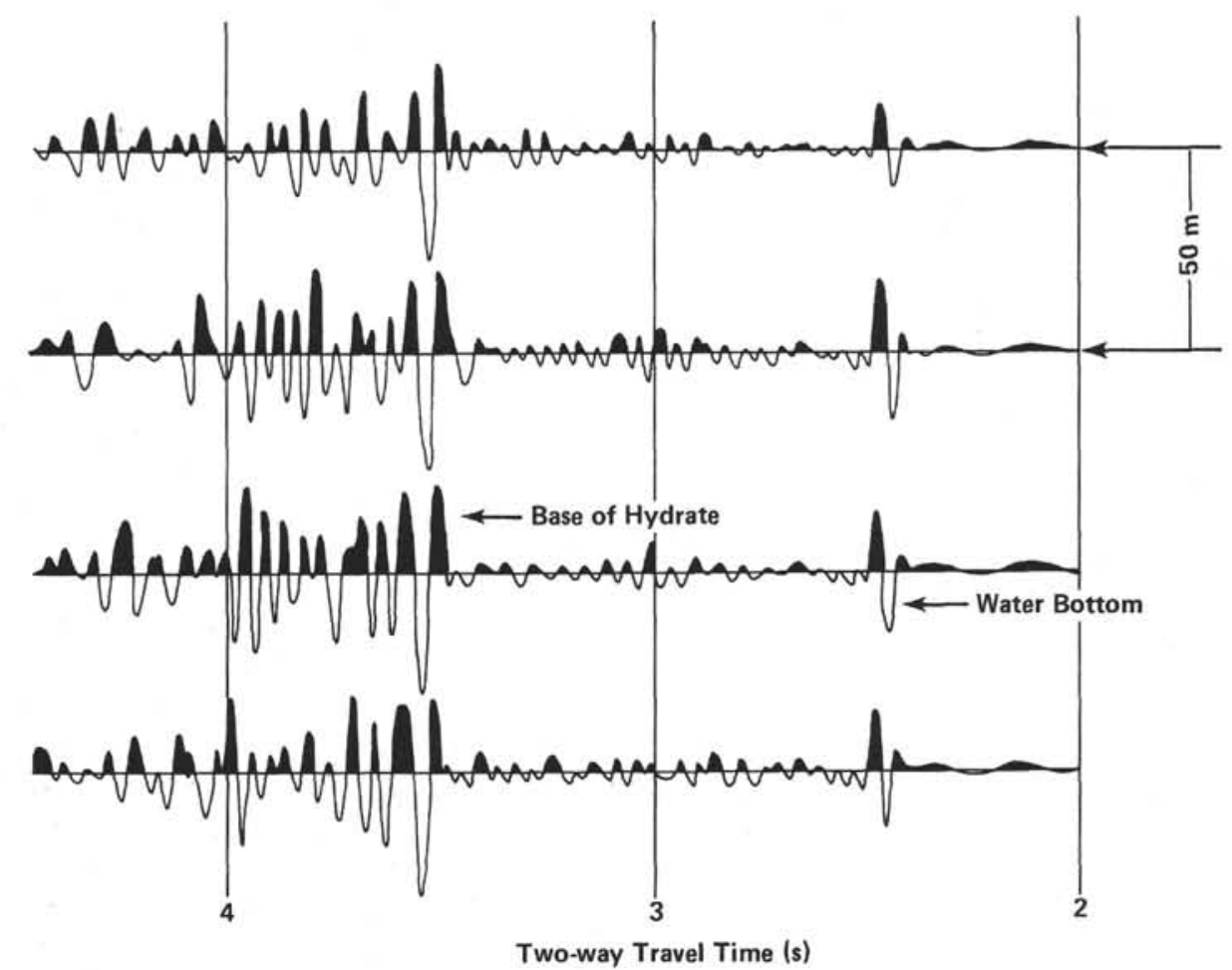

Figure 9. An example of polarity reversal between the water bottom and a strong BSR on GUA-14. (Note the low amplitudes of reflections in the slope sediment above the BSR. Seismic traces are from Ladd et al., [this volume].)

stant velocity of $1.7 \mathrm{~km} / \mathrm{s}$ was used to convert time information to depth. This velocity is inappropriate for the prograding sediment in Figure 7 . The prograding sediment contains more sand than does the slope sediment, as was shown by drilling at Site 496 . Unfortunately, the velocity log was not obtained at Site 496 , but if a velocity of 1.8 to $1.9 \mathrm{~km} / \mathrm{s}$ is used to determine depth of the BSR, these points fall within the field shown in Figure 10 . Such velocities are reasonable, based on semblance analysis and refraction data (see previous discussion). The points are not necessarily inconsistent with the gas-hydrate stability curve, but they are poor points to use in a test for gas hydrate.

Within the Guatemalan field are points from about $100 \mathrm{~km}$ of seismic records (Fig. 1). The correspondence between the Guatemalan hydrate depths and those from other areas and the polarity reversal test suggests that the BSR is a base of gas-hydrate reflection and not a diagenetic boundary. The recovery of gas hydrate is proof of its presence off Guatemala.

The gas-hydrate BSRs are concentrated in the midslope area. They tend to be locally developed where slope deposits are thickest and are generally 100 meters or more above the base of thick slope deposits (Fig. 11). This relation is consistent with a proposed origin of the hydrated methane gas from the $2 \%$ to $5 \%$ herbaceous material in the slope deposits. Samples of rock below the slope deposits at Site 494 have low concentrations of organic carbon, which may explain the absence of gashydrate BSRs in areas of thin slope sediment.

Temperature at the base of the hydrate zone was estimated by using the solid/gas phase relation of the meth- ane gas-hydrate system. These temperatures and depths, and the temperature at the water/sediment interface, gave a temperature gradient that could be compared with temperature gradients from Leg 67 drill holes (Fig. 12) and temperature from the Esso Petrel \#1 Well (Fig. 13). The temperature gradients derived from base of gas-hydrate determinations have a maximum scatter of about $5^{\circ} \mathrm{C} / \mathrm{km}$ and average $30^{\circ} \mathrm{C} / \mathrm{km}$. The temperature sensor left in Hole $494 \mathrm{~A}$ registered a $6^{\circ} \mathrm{C}$ increase in about 10 days before coming to thermal equilibrium at $22 \pm 5^{\circ} \mathrm{C} / \mathrm{km}$ (von Huene et al., 1980). If the single temperature value logged at Site 497 is corrected for drilling effects by adding the $6^{\circ} \mathrm{C}$ change from drilling measured at Site 494 (drilling histories were similar), the temperature falls at the upper range of the temperature field in which gas hydrates are stable. The temperature gradient in the upper 500 meters of the Petrel \#1 Well (Fig. 13) has a broad range of uncertainty if the shallowed determinations at 447 meters are accepted, but this reading was probably affected most by drilling.

The temperature gradients derived from gas-hydrate data are very consistent with those from the bottomhole data (Fig. 12). There appears to be a gradual increase in temperature gradient landward, as has been observed in heat-flow data including DSDP drill holes on the Japan Trench convergent margins (Langseth and Burch, 1981).

\section{DISCUSSION}

In a companion paper, Ladd et al. (this volume) discuss the reflectors that may represent landward-dipping slabs of oceanic material beneath the slope of the Mid- 


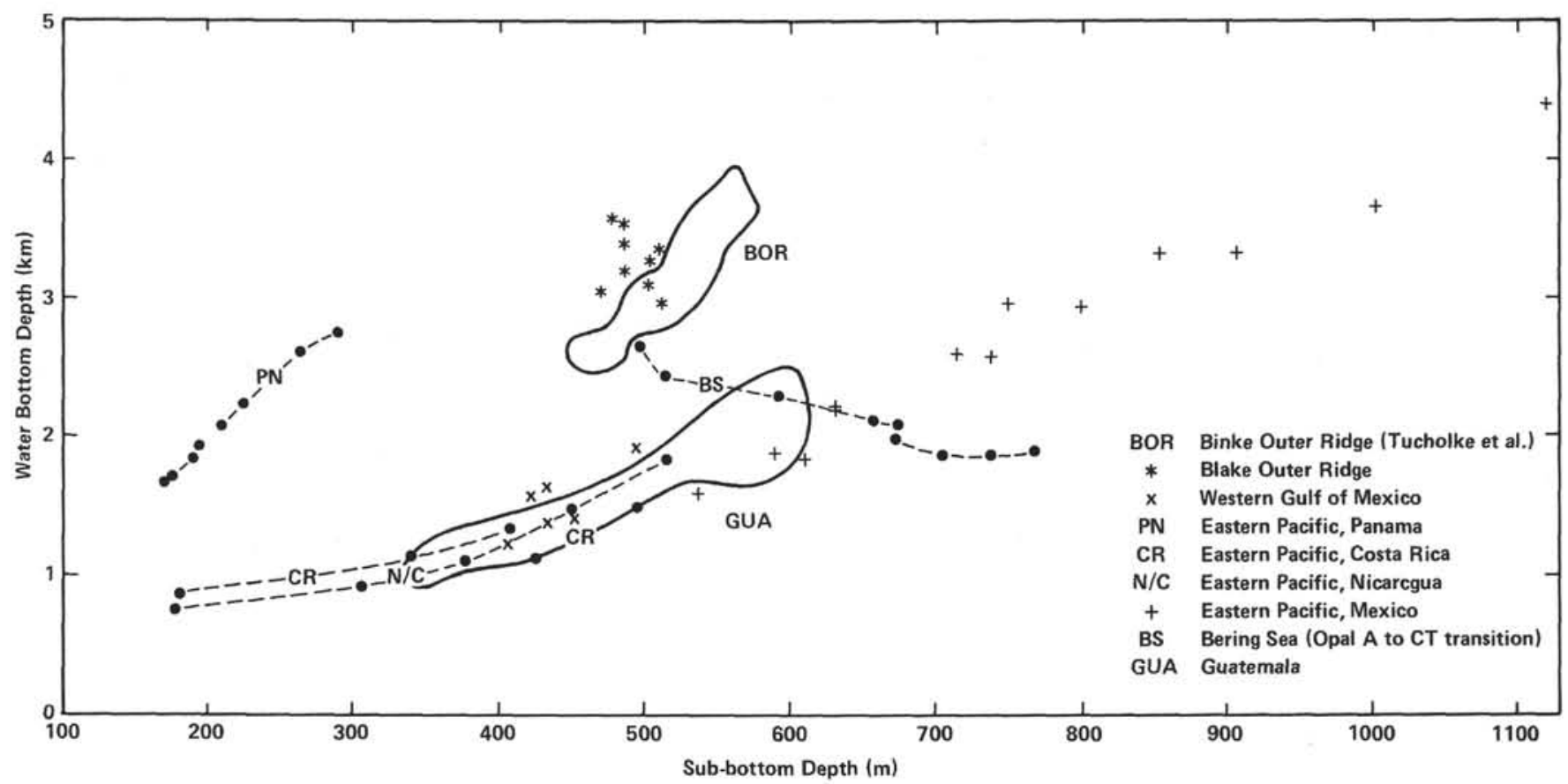

Figure 10. Water depth versus sub-bottom depth to BSRs, after Shipley et al. (1979). (The field marked GUA contains 25 points from BSRs identified off Guatemala. The maximum depth at which gas is stable in the hydrated form will increase with increasing pressures or depth, as is shown for all fields except that of the Bering Sea BSR data. In the Bering Sea, drill samples have shown a diagenetic change across the BSR.)

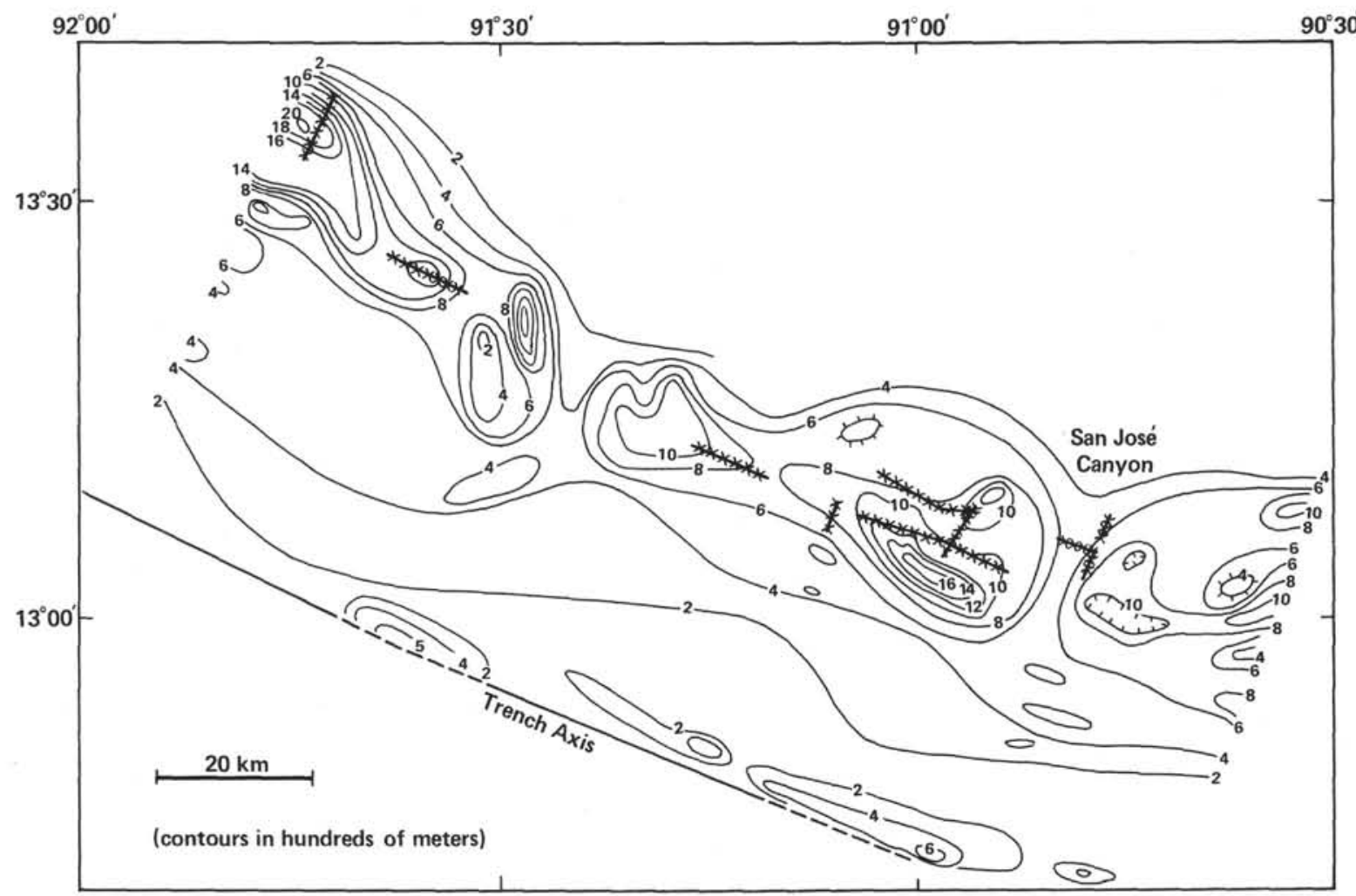

Figure 11. Thickness of slope deposits from the edge of the shelf to the Trench axis. (Lines marked with Xs indicate location of BSRs found in seismic records.) 


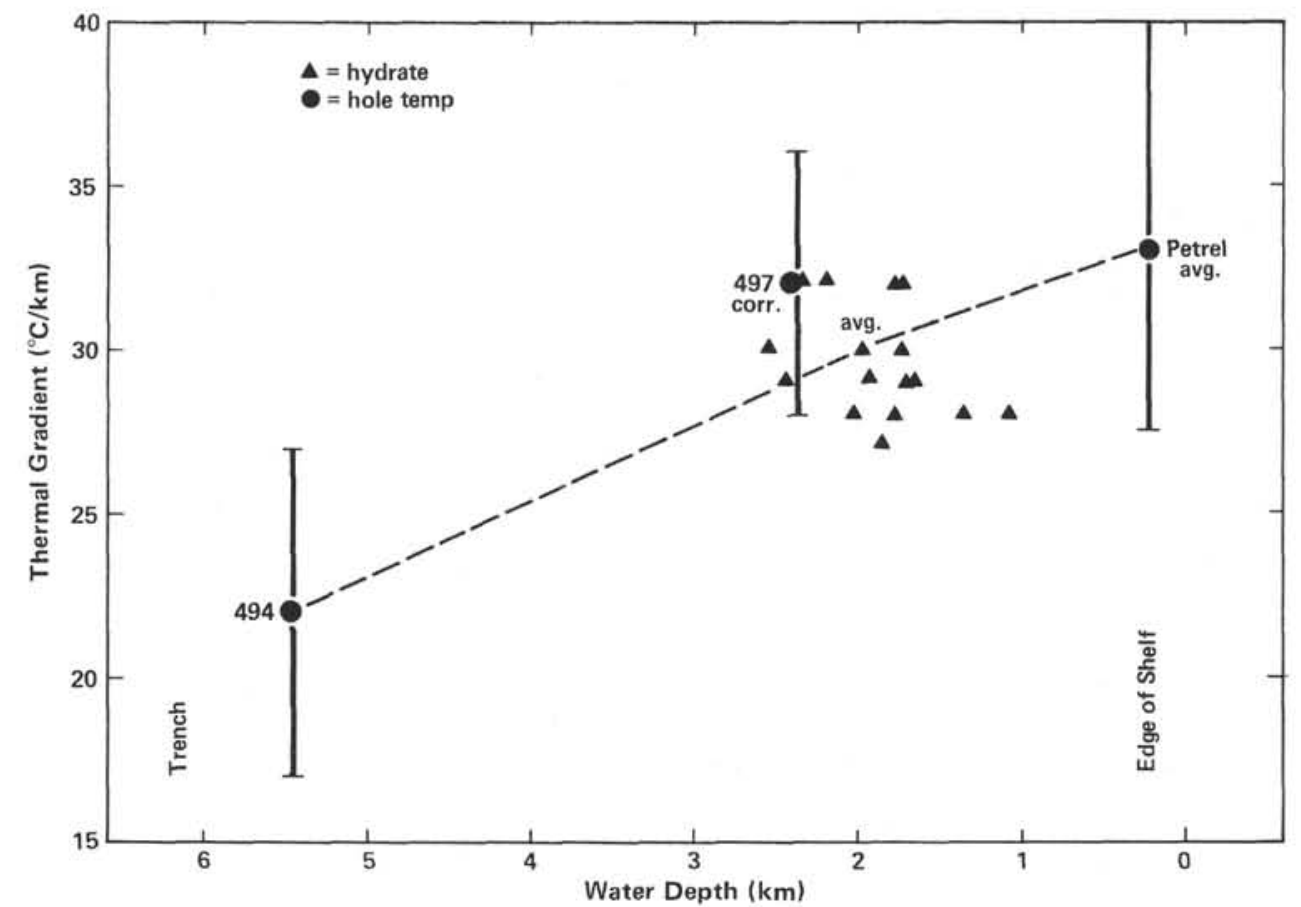

Figure 12. Summary of temperature gradients measured in drill holes off Guatemala and those calculated from the depth of the base of gas-hydrate BSRs. (The temperature at Site 494 was measured in the hole for 1 month after drilling; decay curve applied to corrected thermal gradient, Site 497.)

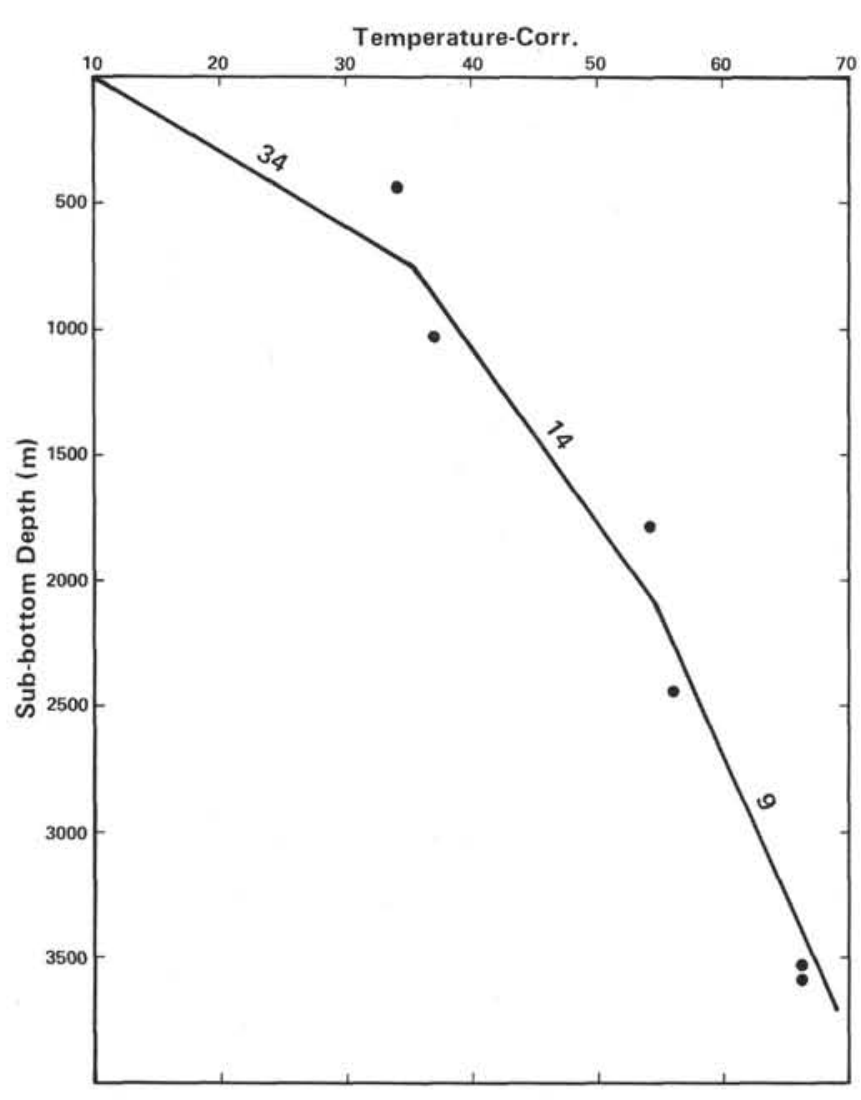

Figure 13. Temperatures from the Petrel \#1 Well corrected for drilling disturbances. (Gradients indicated by numbers along line segments are those assumed for this study. Black circles are the points at which temperature was measured.) dle America Trench off Guatemala. They conclude that slices of oceanic and other material may form an imbricated complex, as first proposed for this area by Seely et al. (1974). Imbrication in the Paleocene or earliest Eocene is inferred from the uplift of a section penetrated in the Petrel \#1 Well (Seely, 1979). Seely (1979) describes two unconformities at the edge of the shelf and associates one with Paleocene uplift and the other with a subsequent Oligocene-Miocene uplift. Angular discordance is greatest across the Oligocene-Miocene unconformity, indicating strong Oligocene-Miocene tectonism at the present shelf edge. The truncation of middle and late Eocene beds by the Oligocene-Miocene unconformity also indicates subaerial erosion at the shelf edge, and Seely (1979) infers fore-arc basin subsidence and lowering of sea level as the principal cause of this angular unconformity. We build on this background in interpreting some of our data and in developing more detail in the tectonic history.

At Site 496 in 2064 meters of water, the prograding slope deposits contain early Miocene fauna from shelf depths. The $\mathbf{2 0 0 0}$ meters or more depth difference since the early Miocene is larger than the postulated 500-meter change in sea level for this period (Seely, 1979), indicating at least local subsidence of the midslope area. On the other side of the shelf edge arch, early Miocene subsidence of the fore-arc basin occurred also (Seely, 1979); therefore early Miocene arching of the shelf edge and subsidence of both the seaward and landward flanks are indicated. Thus in addition to the Paleocene uplift a major tectonic event affected the present shelf edge in the early Miocene. 
Prograding sediment sequences of at least the early Miocene lap against the underlying rocks of the continental framework. This relation suggests that the midslope was first covered by slope sediment in the early Miocene or before. The first slope deposits on the lower slope appear to be early Miocene at Site 494 also (Site 494 report, this volume). If these ages from only two holes on the lower and midslope areas are typical, the present bedrock framework of the Trench slope was assembled and emplaced prior to the early Miocene. From the two points of age control and seismic stratigraphy there is no evidence for progressive imbrication and uplift through the Neogene, as was developed along the Middle America Trench off southern Mexico (Moore et al., 1979). An absence of Neogene imbrication is consistent with the lack of a Neogene accretionary complex at Site 494 .

If not accretion and imbrication, what are the subduction-related tectonic processes that have shaped the landward slope of the Trench off Guatemala during the Neogene? This question lacks a satisfactory answer in the existing data, but some puzzling information on modern structure is seen beneath the lower slope where the overthrust plate is thin.

The ocean crust entering the subduction zone has a horst and graben topography of up to 700 meters vertical relief, formed as the crust is flexed downward along the seaward side of the Trench. Seabeam mapping shows that rather than trending parallel to the Trench, the horst and graben strike $35^{\circ}$ from the trend of the Trench axis (Aubouin et al., Seabeam Survey, this volume). If subduction of a high ridge or deep trough on the lower plate deforms the upper plate, these effects should be marked by an oceanic topographic trend superimposed on the contrasting continental trend of the landward slope of the Trench. A subdued oceanic topography from subduction of ocean crust relief should be most obvious at the thin leading edge of the upper plate or at least at the base of the landward slope of the Trench.

Surprisingly, the Seabeam map shows an abrupt termination of the two completely mapped ridge and trough pairs at the foot of the landward slope of the Trench. Yet seismic-reflection records show relief on the subducted igneous ocean crust, suggesting that much relief of the oceanic basement is not sheared off. Unfortunately the seismic records are insufficient to show whether the two ridges on the Seabeam map continue beneath the landward slope of the Trench. Although the horst and graben relief is subdued by sediment ponded along the Trench axis, the rate of sediment accumulation is insufficient to bury the ridges completely (Sites 499 and 500 reports, this volume). If the two ridges do not end fortuitously at the Trench axis, then much of the deformation from subduction of basement features hundreds of meters high is decoupled somewhere below the slope deposits in a zone that is locally less than $1 \mathrm{~km}$ thick. Even if the ridges end, many other ridges must have been subducted. If the present rate of subduction $(10 \mathrm{~cm} / \mathrm{yr}$.) has existed for $15 \mathrm{~m} . \mathrm{y}$., and the $10-\mathrm{km}$ spacing of ridges and troughs in the Seabeam map is representative of the subducted topography, then at least 150 ridges and troughs have been subducted without impart- ing a diagonal trend on the slope topography. The benches at the base of the slope that are mapped with the Seabeam are subparallel to the Trench axis and do not reflect the horst and graben trend. Their appearance on seismic records suggests collapse features (Ladd et al., this volume, fig. 5), but this origin is uncertain without better definition.

The partially mapped eastern ridge on the Seabeam map (Aubouin et al., Seabeam Survey, this volume) may have shaped the lower slope of the Trench where the foot of the slope and the ridge collide. The topography from the UTMSI bathymetric records show a possible change in trend of the Trench axis parallel to the horst and graben topography at the point of collision (Fig. 3, area A). Thus the subduction of the horst and graben topography seems to be largely passive and perhaps locally active. In order for passive subduction to take place, the upper and lower plates must be highly decoupled.

\section{SUMMARY AND CONCLUSIONS}

1. The acoustic basement, which comprises the bedrock framework of the Guatemalan margin, was emplaced prior to the early Miocene. The basement is considerably more consolidated than the overlying slope deposits, as shown by the markedly greater seismic velocity of the basement. At the one site (494) where basement was sampled, it has greater consolidation and is highly fractured, consistent with the geophysical data. The consolidation of basement seems to have occurred prior to the deposition of the slope deposits and prior to the beginning of volcanism along the present arc. Thus emplacement of basement is a product of a previous tectonic system and is not the result of tectonism during the present arc-trench system.

2. There is insufficient data to indicate the tectonic mechanisms that have shaped the present margin. However, the net result of Neogene convergence does not appear to include accretion of oceanic and trench sediment. If the convergent history indicated by global plate tectonic models and arc volcanism is accepted, the subduction of large amounts of oceanic and trench sediment must also be accepted. Subduction of soft sediment is probably facilitated by the highly decoupled nature of the subduction zone. Such decoupling is emphasized by the seemingly passive subduction of large topographic features on the ocean plate.

3. Seismic records show many areas of prograded slope sediment. These prograding sequences lap against the basement surface and are often the lowest strata in the slope sediment sequence. At Site 496 the prograding sequence is at least early Miocene. The many channels in the present slope topography could be a modern analogue to ancient distributary channels that formed transport paths down the slope. Thus in addition to the hemipelagic sediment that constituted most of the drill cores on the landward slope of the Trench, there are geophysical indications of fan and overbank deposits in the sequence of slope deposits.

4. The gas hydrate recovered at two and possibly three sites is probably common over much of the continental slope off Guatemala. The base of gas-hydrate re- 
flection is now seen beneath much of the slope, especially in areas of thick slope sediment. The association of a base of gas-hydrate reflection with thick slope sediment suggests that slope sediment is the major source of the hydrated gas.

\section{ACKNOWLEDGMENT}

We greatly appreciate the assistance of Brenda MacIsaac, Ronald Phair, and Marie Ferguson in processing the seismic data. Funding for use of the TEMPUS seismic processing system at the University of Texas and travel for $\mathrm{RvH}$ was provided by JOI Inc.

\section{REFERENCES}

Boyce, R. E., 1976. Sound velocity-density parameters of sediment and rock from DSDP drill sites 315-318 on the Line Islands chain, Manihiki Plateau, and Tuamotu Ridge in the Pacific Ocean. In Schlanger, S. O., Jackson, E. D., et al., Init. Repts. DSDP, 33: Washington (U.S. Govt. Printing Office), 695-728.

Couch, R., and Woodcock, S., 1981. Gravity and structure of the continental margins of southwestern Mexico and northwestern Guatemala. J. Geophys. Res., 86:1829-1840.

Ibrahim, A. K., Latham, G. V., and Ladd, J., 1979. Seismic refraction and reflection measurements in the Middle America Trench offshore Guatemala. In Ahrens, T. J. (Ed.), J. Geophys. Res., 84(B10):5643-5649.

Kennett, J., McBirney, A., and Thunell, R., 1977. Episodes of Cenozoic volcanism in the Circum-Pacific region. J. Volcanol. Geotherm. Res., 2:145-163.

Ladd, J. W, Ibrahim, A. K., McMillen, K. J., Latham, G. V., von Huene, R. E., Watkins, J. E., Moore, J. C., and Worzel, J. L.,
1978. Tectonics of the Middle America Trench offshore Guatemala. In International Symposium of the Guatemala February 4 Earthquake and Reconstruction Process (Vol. 1), Guatemala City, Guatemala, May 1978.

Langseth, M., and Burch, T., 1980. Geothermal observations of the Japan Trench transect. In Scientific Party, Init. Repts. DSDP, 56, 57, Pt. 2: Washington (U.S. Govt. Printing Office), 1207-1210.

Moore, J. C., Watkins, J., Bachman, S. B., Beghtel, F. W., Butt, A., Didyk, B. M., Leggett, J., Lundberg, N., McMillen, K. J., Niitsuma, N., Shepard, L. E., Shipley, T. H., Stephan, J. F., and Stradner, H., 1979. The Middle America Trench off Mexico. Geotimes, 24(9):20-22.

Seely, D., 1979. Geophysical investigations of continental slopes and rises. In Watkins, J. S., and Montadert, L. (Eds.), Geological and Geophysical Investigation of Continental Margins: Tulsa, Ok. (Am. Assoc. of Pet. Geol. Mem. 51).

Seely, D. R., Vail, P. R., and Walton, G. G. 1974. Trench slope model. In Burk, C. A., and Drake, C. L. (Eds.), Geology of Continental Margins: New York (Springer-Verlag), pp. 261-283.

Shipley, T. H., Houston, M. H., Buffler, R. T., Shaub, F. J., McMillen, K. J., Ladd, J. W., and Worzel, J. L., 1979. Seismic evidence of widespread possible gas hydrate horizons on continental slopes and rises. Am. Assoc. Pet. Geol. Bull., 63:2204-2213.

Shor, G. G., and Fisher, R. L., 1961. Middle America Trench: seismic refraction studies. Geol. Soc. Am. Bull., 72:721-730.

von Huene, R., Aubouin, J., Azéma, J., Blackinton, G., Carter, J. A. Coulbourn, W. T., Cowan, D. S., Curiale, J. A., Dengo, C. A., Faas, R. W., Harrison, W., Hesse, R., Hussong, D. M., Ladd, J. W., Muzylöv, N., Shiki, T., Thompson, P. R., and Westberg, J., 1980. Leg 67: The Deep Sea Drilling Project Mid-America Trench transect off Guatemala. Geol. Soc. Am. Bull., 91:421-432. 